\title{
ABSTRACT ()F ADMINISTRATIVE REPORTS ON THE OJI RIVER LEPER SETTLEMENT AND CLINICS FOR THE YEARS 1941 \& 1942
}

\author{
DR. T. D. F. MONEY
}

These reports, which have only recently been received, deal mainly with administrative matters. Their principal points can be summarised as follows:

The principles on which the campaign against leprosy is based are:-Firstly; the offer of treatment to all suitable patients who ask for it, the limitations of the areas in which it can be provided being dependent on financial resources. About three-fifths of the worst affected areas of the Onitsha Province are now within reach of a treatment centre. Secondly, children being specially susceptible require to be protected from contact with highly infectious leprosy cases. Thirdly, the support of public opi

by means of addresses before Native Administrations and Church leaders. Fourthly, whenever possible those under treatment are trained to assist, under supervision, in giving treatments, keeping records, nursing and laboratory work. They now number about one hundred. Fifthly, the fullest use of this trained African staff is made to relieve the small number of Europeans available. During the last five years a trained African staff has thus been built up, with the help of the Church Missionary Society which bears the whole cost of educating and employing the indigenous staff. They enable the usefulness of the small European staff to be extended and make for more efficient working during the leave periods of the latter, and their employment also reduces expense. The settlement, which is the base of the whole work, is isolated in the jungle and transport is difficult.

Development of Methorls over the last Five Years. A European Clinic Officer, with his African Assistants, visits each of the five divisions every week. The Therapeutic Section gives intramuscular and intradermal injections, together with general treatment and dressings to those requiring them; the Clerks deal with the treatment records of the hundreds of cases attending the clinic, and the Diagnostic Section makes the clinical records both of new cases and of those undergoing re-examination after treatment, and prepares specimens from all cases for bacteriological examination. 
In view of the very large number of cases to be treated, oral treatment with hydnocarpus oil is being used for patients whose disease has ceased to be active preparatory to their discharge. In I94I a Preventive Workers Section was formed from the African staff to deal with the dangerously infective type of cases discovered through the offer of treatment. A pair of such workers visit the infective cases in their hou

tive form of segregation possible under the circumstances, with special attention to the protection of children from contact with them.

At the settlement itself accommodation has been provided for patients coming from long distances for examination, and other administrative improvements have been made. The records of patients number over 14,000 and their registration is complicated by some of them not always using the same of several names. A Statistical Section has been established to abstract the records.

Education. The inclustrial school has been extended and technical training is given in the nurses school. Education of the patients gives those discharged an interest in the problem of leprosy which enables them to be employed in village anti-leprosy work; those who enter as children and remain for some years are most influenced. The Education Department of the Government has given a helpful grant, but the appointment of a non-patient trained teacher would be of great value.

Agriculture and Industries. In addition to the communal farms, brick making and other industries have been organised with unpair patients' work, except for overtime; the net gain on these operations in 1940-4I was $£ 28$ I9s. $5 \frac{1}{2} \mathrm{~d}$. The great majority of the patients in the Settlement support themselves on their private farms and contribute a portion of their time in unpaid work in the settlemen $t$.

Finance. The estimates for the year 1939-40 were :-From the Native Administration $£_{1}, 000$, from the B.E.L.R.A. Nigeria Branch $£_{\mathrm{I}}, 000$, miscellaneous $£ 40$, making a total of $£_{2}, 040$, and the financial arrangements were practically the same in the following financial year. The African Settlement Staff was financed by the Church Missionary Society at an estimated cost of $£ 404$. The teachers in the African Staff school were separately provided for.

Owing to shortage of European staff African Clinic Supervisors, sisters and nurses trained in the Settlement carry on much of the work at clinics, under the direction of a medical officer, who visits the clinics once a fortnight. Preventive workers visit the 
patients' houses and advise on the segregation of infective cases. The patients now pay Io/.. on admission to the settlement towards the construction and maintenance of patients' houses, and they guarantee their support during the first year until their farms come into production, and contribute some labour in the settlement. In 1942. a trained teacher was appointed and more patient teachers have been appointed in. view of the increasing number of rhildren in the settlement.

The following tables summarise the great amount of work that is being carried on in the Settlement and its surrounding clinics:-

\section{STATISTICS}

A. Settrlement.

1. Patients resident.

Adult males ...

Adult females

Male children

Female children

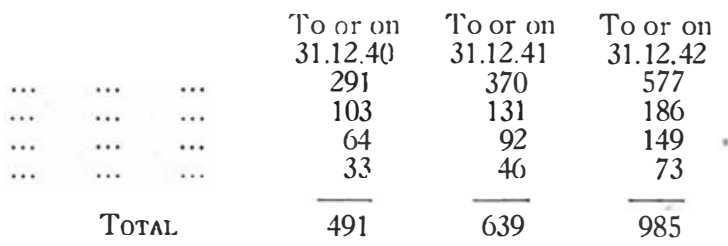

2. Hospital.

Admission, Settlement Patients

" C.linic patients ...

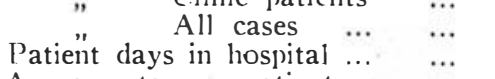

$\begin{array}{llll}\text { Average stay per patient } & \ldots & \ldots \\ \text { Jeaths } & \ldots & \ldots & \ldots \\ \text { Oea } & \ldots & \ldots\end{array}$

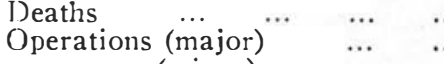

11342

$\begin{array}{cccc}\ldots & \ldots & \ldots & \text { Not entumerated } \\ \text { (minor) } & \ldots & \ldots & 21 \\ & \ldots & \ldots & \text { Not enumerated }\end{array}$

$\begin{array}{rr}194 & 241 \\ 41 & 55 \\ 235 & 296 \\ 10486 & 12211 \\ 45 & 41 \\ 8 & 63 \\ 43 & 16 \\ 40 & 78\end{array}$

3. Babies' Home (for infants of infectious mothers) ... ...

0

4. Laboratory'.

Bacteriological (smear) exami$\begin{array}{llll}\text { nations } \ldots & \ldots & \ldots & \ldots\end{array}$

Other examinations $\ldots \ldots$

5. Dispensary.

$$
\text { TOTAL }
$$

\begin{tabular}{|c|c|}
\hline $\begin{array}{r}8695 \\
343\end{array}$ & $\begin{array}{r}8379 \\
329\end{array}$ \\
\hline 9038 & 8708 \\
\hline
\end{tabular}

Hydnocarpus Oil prepared and issued in sterile containers ...

2051 pts. 2240 jts. 2361 pts.

B. Clinics.

1. Patients Registered, 1941.
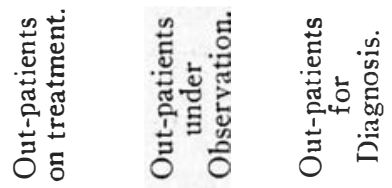
2. Clinic Attendances, 1942.
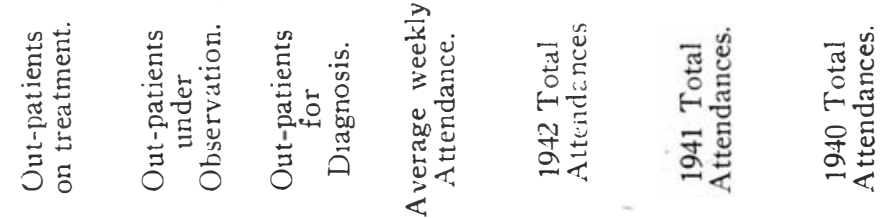

Totals 200,372 $, 840 \quad 2,870$

$4,100 \quad 205,082$

224,406 158,336

C. Treatment Given. 1942.
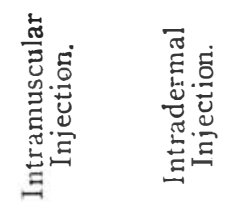

壱葋

હ્

Totals $230,125 \quad 61,616 \quad 52,279 \quad 344,020$ 